\title{
評価項目が街路景観評価に及ぼす影響 THE CONTRIBUTION OF CONSTRUCTS TO STREETSCAPE EVALUATION
}

\author{
橫究*, 乾 正雄**, 中村芳樹*** \\ Kiwamu MAKI, Masao INUI and Yoshiki NAKAMURA
}

\begin{abstract}
The objective of this study is to determine the contribution of constructs to streetscape evaluation. At first, we tried to find the correlations between constructs and streetscape rating by correlation coefficient or multi-regression equation technique, using the scores on semantic differential scales. Sometimes we found very slight correlation. This means that the first appproach failed to measure the contribution. Considering the cause of this failure, we made two modifications to gain more valid results: 1. because the same construct may or may not be contributing to the rating of a streetscape, its scores should be used only when it is proved to be contributing, and

2. because there are opposite feelings towards the same construct, scores of such a construct should be divided and counted as positive and negative contributions to streetscape value.

Modified calculation of the contribution of constructs from the experiment data that take the above two points into account has proved successful.
\end{abstract}

Keywords : The Visual Environment, Streetscape Evaluation, Construct, Preference

視環境、街路景観評価、評価項目、好ましさ

1.はじめに

好ましい街路景観とはどういうものなのかを考えると きには、街路景観の評価構造を表現したものがあるとよ い。街路景観の評価構造とは、街路景観の評価を行う際 に人々が考慮している項目（評価項目）と、それらが街 路景観評檤に及ほす影響（評㑑項目の影響少）を体系的 に示したものである。このようなデータに基づいて、ど のような評価項目が街路景観評価に大きな影榔を及ぼ ているのか、人によって好みの景観が異なるのはなぜか などということを明らかにしていくことが、好ましい街 路景観像を明確にしていくことにつながると考える。

筆者らは、街路景観の評価棈造を明らかにするための 一連の研究を行っており、既報1においては評価構造が 安定して表現できる街路景観の範囲を明らかにしてい る。次に行うべきことは、备々の評価項目が街路景観評 洒に及隹す影響を正確に把挃することである。そこで、 街路景観スライドを提示した評定実験を行い、評価項目
が街路景観評优に及ばす影謷の大きさを定量的に把握す ることにした。その詳紐は次節で述べるが、評洒項目の 影響力を表すと考えられた各評佂項目の評定值と街路景 観評佂「好ましさ」の評定値の間の相関係数や偏回帰係 数の中に、それらが0に近い值を示すものが含まれてい た。これは、評価項目が街路景観評価に影響を及はして いないということを意味することになり、明らかに矛盾 である。つまり、この実験・解析手法では、評価項目が 街路景観評洒に及はす影響を正確に把握できていない可 能性があるということになる。

本研究は、このような矛盾が起こる原因を明らかに し、評価項目が街路皿観評価に及ほすす影響を正確に抽出 することを目的としている。そのために、矛盾が起こる 原因として考えられるものを整理し、それらを考慮する

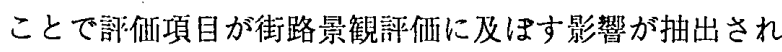
ることを、被験者実験を行って確恝するという手順で研 究を進めていく。
Research Student, Tokyo Institute of Technology, Dr. Eng.

Prof., Tokyo Institute of Technology, Dr. Eng.

Associate Prof., Tokyo Institute of Technologuy, Dr. Eng. 
表一1 評価項目と街路景観評価の関連

（A）因子得点と街路暴観評価の關連

\begin{tabular}{|c|c|c|}
\hline & 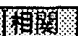 & \\
\hline 〈落ち竞き・方 & 0.61 & \\
\hline 〈明るさ 面 & & \\
\hline スケール感 & 0.00 & \\
\hline
\end{tabular}

（B）感した人敨と街路景観即価の関连

\begin{tabular}{|c|c|c|}
\hline 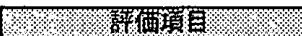 & 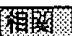 & 15 \\
\hline あこがれのある & 0.73 & 1.31 \\
\hline ゆったりとした & 0.81 & 0.84 \\
\hline エ夫を感じる & 0.71 & \\
\hline 安らき & 0.61 & 0.6 \\
\hline 新鮮な & 0.59 & 0.66 \\
\hline 発見ありそう & 0.54 & 0.61 \\
\hline 変化のある & 0.45 & 0.48 \\
\hline おしゃれ & 0.63 & 0.47 \\
\hline 高級感のある & 0.53 & 0.44 \\
\hline 悄緒のある & 0.41 & 0.4 \\
\hline 異国風の & 0.47 & 0.41 \\
\hline 漞しみを感じる & 0.51 & 0.39 \\
\hline 溜滋な & 0.56 & 0.35 \\
\hline 歴史を感しる & 0.22 & 0.26 \\
\hline 㵝かしい & 0.25 & 0.23 \\
\hline 計画された & 0.27 & 0.13 \\
\hline 昔ながらの & 0.10 & 0.07 \\
\hline 近代的な & 0.05 & 0.02 \\
\hline 生活に密着している & 0.02 & 0.01 \\
\hline 日本的な & 0.01 & 0.01 \\
\hline 生活の様子が感しらうる & 0.00 & 0.00 \\
\hline 庶民的な & -0.09 & -0.0 \\
\hline 人工的な & -0.32 & -0.1 \\
\hline 計画のない & -0.37 & -0.2 \\
\hline 污5しい & -0.39 & -0.3 \\
\hline 安っぽい & -0.42 & -0.3 \\
\hline 般風量 & -0.58 & -0.38 \\
\hline 下品な感じ & -0.38 & -0.41 \\
\hline 平凡な & -0.45 & -0.43 \\
\hline 外に出ているもの目障り & -0.49 & -0.60 \\
\hline ゆとりのない & -0.78 & -0.60 \\
\hline 疲れる & -0.77 & \\
\hline
\end{tabular}

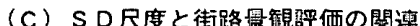

\begin{tabular}{|c|c|c|}
\hline 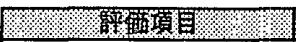 & 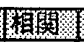 & D㻼: \\
\hline 歩いてみたい & 0.93 & 0.90 \\
\hline 色が調和している & 0.57 & \\
\hline 開放感のある & $0 . \overline{70}$ & 0.84 \\
\hline 建物と周田が調和してい & 0.55 & 0.79 \\
\hline 歩きやすい & 0.53 & 0.79 \\
\hline 建物が良い & 0.72 & 0.74 \\
\hline 建物のデザインがよい & 0.69 & 0.72 \\
\hline 建物の色がよい & 0.67 & 0.68 \\
\hline 美しい & 0.82 & 0.68 \\
\hline 建物の蓀袄がよい & 0.56 & $0 . \overline{62}$ \\
\hline 明るい感し & 0.57 & 0.60 \\
\hline 落ち禬きがある & 0.71 & 0.5 \\
\hline 面白みがある & 0.66 & 0.5 \\
\hline 個性のある & 0.63 & 0.5 \\
\hline 暖か心感し & 0.58 & 0.5 \\
\hline 空がよく見える & 0.41 & 0.5 \\
\hline 緑が多い & 0.58 & 0.55 \\
\hline 色が明るい & 0.26 & 0.48 \\
\hline 身近な感し & 0.43 & 0.4 \\
\hline 全体にまとまりがある & 0.55 & 0.4 \\
\hline 椂が手入れされてし & 0.43 & 0.38 \\
\hline 籢然としている & 0.38 & 0.2 \\
\hline 人々の交流ありそう & 0.22 & 0.15 \\
\hline 見通しがきく & 0.14 & 0.18 \\
\hline 歩道が整備されている & 0.20 & 0.16 \\
\hline 建物が似ている & 0.14 & 0.11 \\
\hline 広い & 0.09 & 0.1 \\
\hline 新しい & 0.17 & 0.1 \\
\hline 䖯道が広い & 0.09 & 0.08 \\
\hline 生活を感しる & 0.09 & 0.0 \\
\hline スケールの小さな & 0.04 & 0.0 \\
\hline 活気がある & -0.08 & -0.0 \\
\hline 道幅広い & -0.09 & -0.0 \\
\hline 人通り多そう & -0.20 & -0.2 \\
\hline 色の数が多い & -0.21 & -0.2 \\
\hline 建物が高い & -0.28 & -0.2 \\
\hline うるさそう & -0.48 & -0.5 \\
\hline 賁板が気になる & -0.55 & -0.5 \\
\hline 車が気になる & -0.43 & -0.5 \\
\hline
\end{tabular}

表の（A）は、評価項目（16 対のS D尺 度：（C）の*印）の因子分析で得られた 3 因子について、その因子得点と「好ましさ」 の平均評定值の相関係数および偏回帰係数を 求めたものである。因子分析の詳細について は、既報1実験 3 を参照されたい。

次に、（B）と（C）の違いについて説明 しておく。（B）の項目は、棓価項目を感じ るか感じないかの 2 値的な選択を行わせた。 それに対し、（C）は通常のS D尺度で評定 させている。（B）のデー夕採集法を採用し たのは、被験者の負担を減らすためである。

(B) の部分の相関係数および偏回㷌係数 は、各評伍項目を感じた人数をもとに計算し ている。それに対し、（C）の部分の相関係 数抢よび偏回帰係数は、各評価項目の平均評 定値をもとに計算している。

人々に強く感じられる項目ほど、多くの人 が感じると述べるであろうから、（B）と

（C）の評価項目は、ある程度比較可能であ ろう。ただし、（B）の偏回帰係数の值は、 全体として（C）と同程度の分散になるよう 調節したため、1.00以上の値を示すケースも あり、（C）との比較は参考程度にとどめる べきだと考える。

\section{2. 評価項目の影響力抽出手法の問題点の検討}

（1）回帰分析を用いた評価項目の影響力の抽出

まず、前節で触れた評定実験およびその解析手法を採 用した理論的背景を説明し、この手法自体に問題点がな いかを検討する。

評価項目の影響力を定㼁すると、評価項目が評価対象 の総合的な評価（本研究では街路景観の好ましさ）を変 化させる程度のことだと言えよう。これは、意思決定の 理論のひとつである多属性効用理論において効用という 言葉で表現されているものと同じものである。この理論 では、ひとつひとつの属性（評価項目）が総合的な評価 を変化させる力、つまり効用を持っており、総合的な評 価はそれらひとつひとつの効用を統合したものだ、と考 えられている。2)

この理論に基づいて、各属性の効用を求めるときに は、評定実験のデータをもとに、属性の值を説明変数、 総合的な評価を被説明変数とした重回帰分析を行い、偏 回帰係数を求めることが一般的である。注 1

そこで、次のような評定実験を行った。

実験 1 〔評価項目と街路景観評価の関連度の抽出実験〕

東京およびその近郊で撮影した街路景観スライド68枚
を提示し、71の評価項目と街路景観評価「好ましさ」の 計72項目を被験者に評定させた。評価項目としては、あ らかじめレパートリーグリッド発展手法3ににより抽出し ておいた街路景観評価の理由を用いている。被験者は、 学生40名〔男性21名／女性19名、建築系22名／非建築系 18名了である。注2

評佃項目として、街路景観評価の判断になんらかの影 響を及はしているはずである評価の理由を用いたのであ るから、街路景観評価「好ましさ」と各評洒項目の評定 値の間の偏回帰係数を計算すれば、それはある程度の大 きさを持つはずである。ただし、偏回帰係数は評価項目 間に独立性が確保されていないと、非常に不安定になる 場合があることが知られており、街路景観の評価項目の ように、互いに相関のある項目を説明変数として用いる 場合には、単純に偏回帰係数を計算すると、0に近い值 を示す可能性がある。そこで、評価項目間に独立性を確 保したデータで、偏回州係数を算出する必要がある。

それには、2つの方法が考えられる。ひとつは、評価 項目を統合するなどの処理を行い、評佂項目間に独立性 が確保されるまで、説明変数を皎り込むというものであ 
る。表一1（A）は、因子分析で説明変数を絞り込み、 説明変数間に独立性を磪保したものである。もうひとつ は、一度に多数の説明変数を用いるのではなく、評価項 目と総合的な評価の関係を、ひとつずつ捉えるというも のである。これは、説明変数をひとつにすることで、独 立性を考虑する必要をなくしてしまおうという考え方で ある。表一1（B）（C）は、この考え方に基づいて、 単回帰分析で偏回帰俰数を算出している。

しかし、どちらの方法を用いても、偏回帰係数が 0 に 近いものが存在している。参考のために、独立性などの 制約のない相関係数も計算してみたが、これも0に近い 值を示しているものがある。注3

これらの值は、手法の制約条件を十分考慮した上で求 めたものである。それにも関わらず、評価項目の影響力 が抽出されない場合があるということは、解析に用いた データが、評価項目の影榔力を抽出するのにふさわしく ないものであったのだと考えざるを得ない。

\section{（2）回帰分析を用いた影響力抽出の問題点}

データの側から評価項目の影響力が抽出されない原因 を考えた場合、次の 2 つの可能性が考えられる。

ひとつめは、評価に関連していないときのデータを混 ぜて解析している可能性である。実験 1では、インタ ビューで述べられた評価の理由をすべての街路景観シー ンの評㑛項目としている。しかし、これらの評価項目 は、理由として挙げられた景観では評価に関連すること は確実であ万うが、それ以外の景観においても評価に関 連しているかどうかは、確認されているわけではない。 もし、評価に関連する評価項目がシーンにより異なって いるなら、すべてのシーンのデータを用いて解析すると いうことは、評価に関連しないケースも含めて解析する ことになる。それが、影噼力を抽出できない原因である かもしれない［図一１（1）]。そこで、評価に関連し ていることが確実なものだけを集めたデー夕をもとに、 評価項目の影響力を算出する必要があると考えられる。

ふたつめは、影響力の異なるデー夕を混ぜて解析して いる可能性である。実験1の解析では、街路景観部価と の関連を評価項目ごとに算出している。これは、評価項

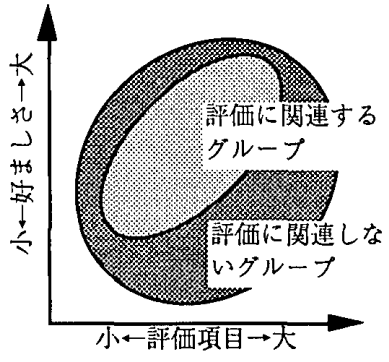

〔全体では関連が消えてしまう〕

(1) 評価との関連の有無

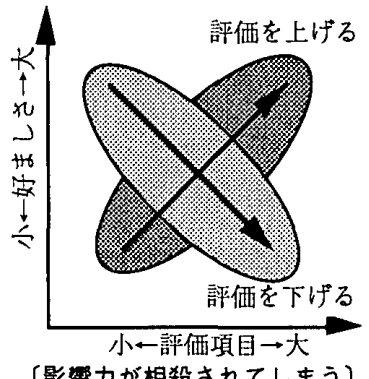

〔影野力が相殺されてしまう

（2）方向性の違い
A図一1 評価項目の影響力が抽出されない原因
目がどのシーンでも同じような影響力を持っているなら ば、妥当な解析方法である。しかし、実験 1 でレパート リーグリッド発展手法により評值の理由を採集したとき に、同じ言葉で表現されていながら、評価を上げる理由と しても、下げる理由としても抽出されたものがあった[表 一2]。もし、評価に及はす影響の方向性に、このような 違いがあるならば、それを分離していないことが影響力を 抽出できない原因であるかもしれない［图一１（2）]。 そこで、同じ言葉で表される評価項目であっても、影響力 の方向性で分離してから影響力を算出する必要があると考 えられる。

この 2 つ可能性を考虑することで、前述した実験・解 析手法では抽出されなかった評価項目の影響力が抽出され るかどうかを確認するために、被験者実験を行ってデータ を採集し、実際に影響力を算出することにした。

\section{3. 評価項目の影響力の抽出手法}

（1）評価項目の影響力を抽出するためのデータの採集 前述した $2 つ の$ 可能性を確かめるには、次のようにデー 夕を採集し、解析すればよいと考えた。

(1)評価に関連することが確実なケースだけを用いて、影響 力を算出すること

被験者が椨価の理由として挙げた項目は、評価に確実に 関連していると考えられる。そこで、各街路景観シーンの 評価の理由を記述させ、理由として挙げられたケースだけ を影響力の算出に用いる。

(2)影噼力の方向性で分離して、影瑤力を算出すること

被験者に各評価項目の影響力の方向性を記述させる。影 響力の算出は、同じ言葉で表現される評価項目であって も、影響力の方向性ごとに分けて行う。

実際に行った実験の概要を以下に示す。

\section{実験 2 【街路景観評価の理由の記述】}

東京およびその近郊で撮影した街路景観のスライド68枚 （実験 1 で用いたもの）を被験者に提示し、街路景観の好 ましさの評価と、その評価の理由を記述させた。被験者 は、学生25名〔男性15名/女性10名、建築系17名/非建 築系8名]である。

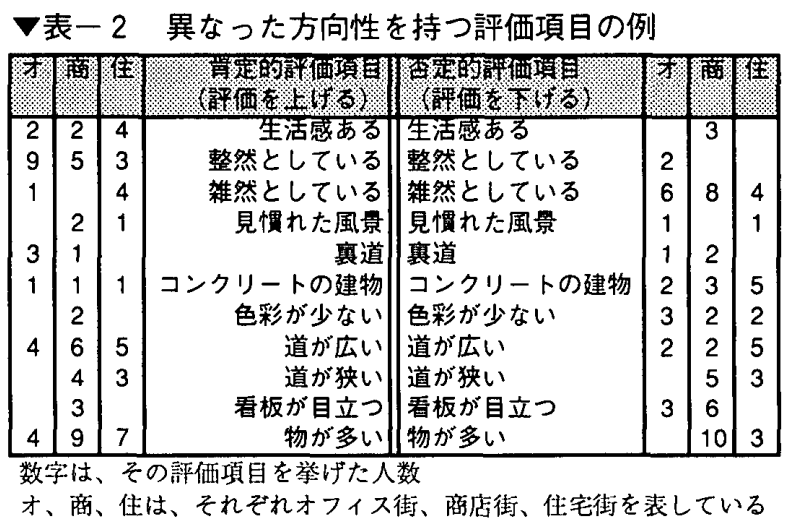




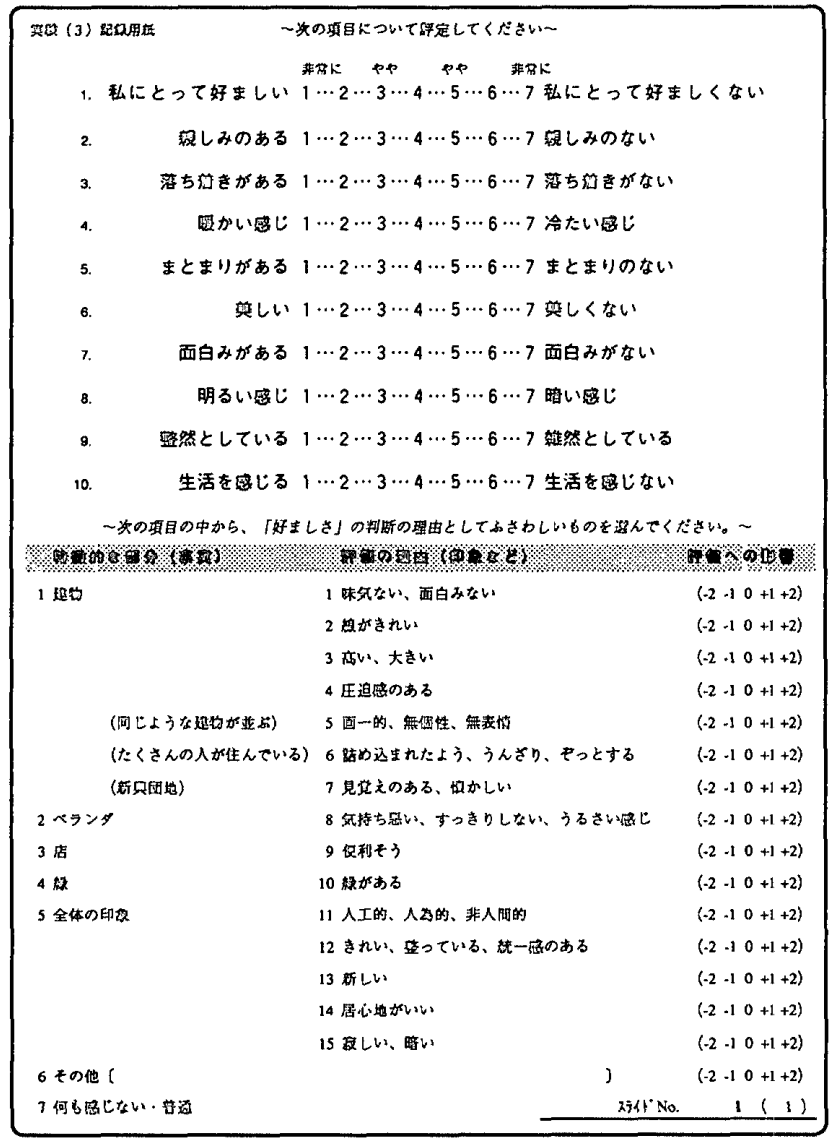

图一2 実驗 3 で用いた評定用紙（图一3の団地の例）

この実験は、各街路景観シーンの評価項目の候補を抽出 することが主な目的である。実験で集められた評価の理由 （評価項目）は、実験者 2 名の合議制により、シーンごと に似通った意味のものを整理して、19以下の項目にまとめ た。これが図ー2に示す実験 3 の評定用紙の下半分の部分 にあたり、シーンごとに異なる項目が並んでいる。

\section{実験 3【街路景観の評価とその理由の選択】}

実験 3 では、実験 1 ・ 2 と同じスライドを被験者に提示 して、整理された評価の理由の中から好ましさを評定した ときに感じていたものを選択させた。さらに、選択された 項目については、それが評価に及はす影響（好ましさの評

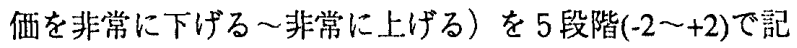
述させた。このことで、どの評価項目が評価に関連してい るのか（評価の理由であるのか）、それが評価にどの程度 の影響を及ほしていると認識されているか（被験者が認識 している評価項目の影厩力の大きさ）を把握することがで きる。この被験者が認識している評価項目の影響力の大き さのことを、今後、評価項目の影響度と呼ぶことにする。 また、「好ましさ」を含む10対のS D 法 7 段階尺度によ り、各シーンの印象の変化をとらえている。被験者は、学 生29名〔男性10名／女性19名、建築系21名／非建築系8 名]である。

なお、すべての実験で、特別な目的を持っているわけで

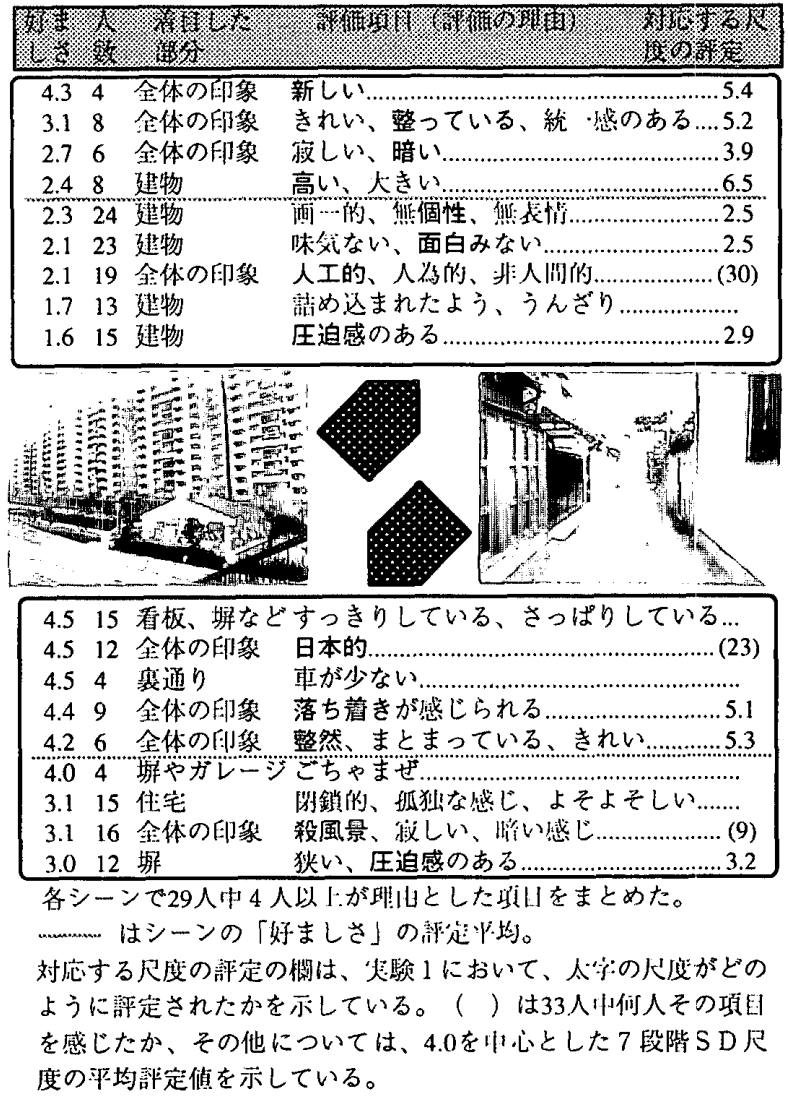

图ー3 シーンごとの評価項目、および評価項目を理由として 挙げた人の好ましさの評定平均

はなく、ぶらぶらと道路を歩いてきて、ある街並みに出 会った状態を想定するよう教示している。

\section{(2) 評価項目の影啷力の抽出手法}

実験 $2 \cdot 3$ から、評価の理由、つまり評洒に関連する 評価項目は、被験者により、街路景観シーンにより、 様々であることが確認された。それは、実験 3 で被験者 が評価の理由として挙げた評価項目を、4つのシーンに ついてまとめた図一3にも表れている。評価項目はバラ エティーに富んでおり、シーンごとの特徎と関連して変

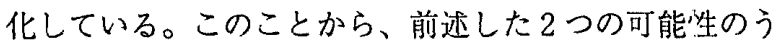
ち、(1)を検討する必要性が確認されたことになる。

そこで、実験 3 で採集したデータを用いて、評価項目 の影響力を抽出することになるのだが、このとき相関係 数や偏回帰係数を用いることはできない。というのは、 これらは変数間の関連性をもとにしているので、評価項 目が理由として挙げられたときのデータだけでなく、理 由として挙げられないときのデータもないと、影㫼力を 算出できないので、可能性(1)を検討するには、不都合が あるからである。

そこで新たに、ある評価項目を理由として挙げた全て のケースの総合的な評価の評定平均值を、その評西項目 の影響力とする方法を提案する[図一４］。この方法を 用いると、例えば、評価項目「まとまり」が街路景観評 


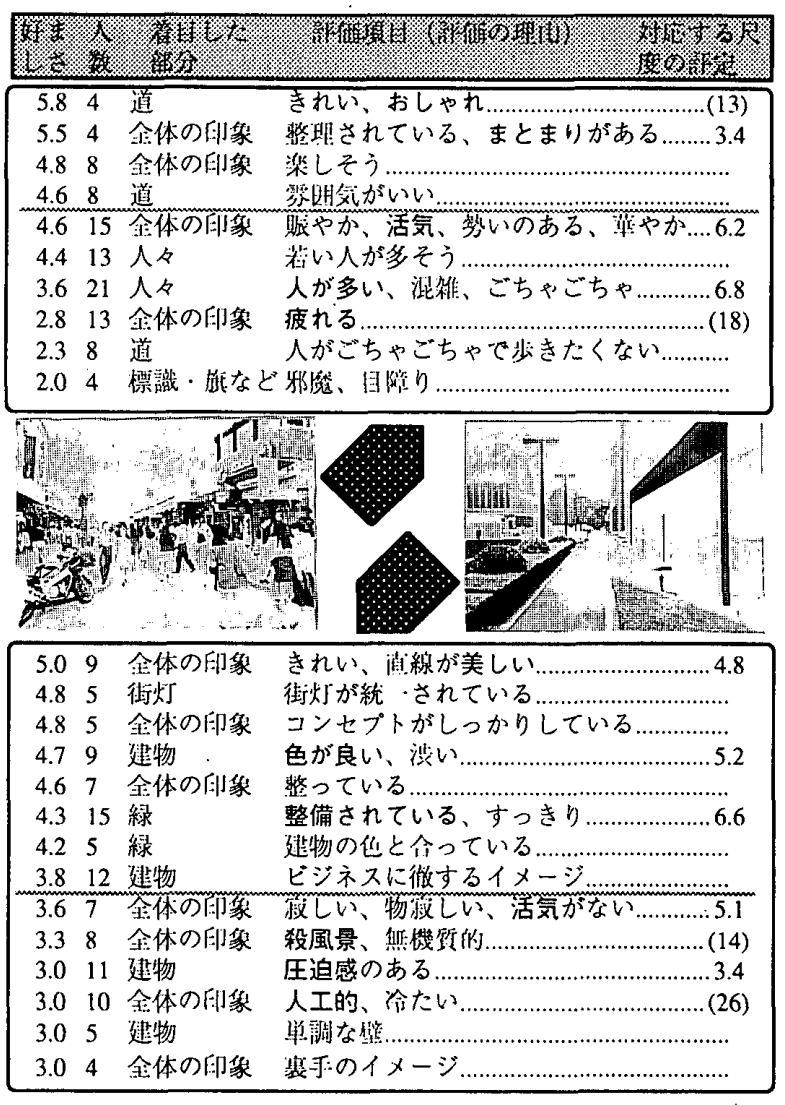

価「好ましさ」に及ほす影響は、被験者が「まとまりがあ る」を理由として挙げた全ての街路鲸観シーンの「好まし さ」の評定平均として算出されることになる。

さて、この方法では、対象となっている評価項目以外の 評価項目の影響力が総和として0になると仮定しているこ とになる注4。しかし、この仮定が採集したデータにおい て満たされているかどうかを直接検証することはできな い。ゆえに、新たに提案した影響力抽出手法の有効性は、 垁験 3 のデータから実際に計算された謤価項目の影響力 が、一般的な感覚に合致するか、論理的整合性があるか、 などの事柄から間接的に確認することになろう。

そのために、いくつかの提示刺激について、評価項目ご とにSD尺度「好ましさ」の平均評定值を算出した [図一 3）。評価項目はシーンによって異なるが、それぞれシー ンの評定平均付近を境に、一般的に好ましい評価項目とし て挙げられるものと好ましくない評価項目として挙げられ るものに分けることができる。また、同じ言葉で表現され る項目（きれい、压迫感のある、殺風景などを参照）は、 各シーンに㧍ける相対的な位置がほほ一定である。これら のごとから、提案した影響力の抽出手法は、ある程度有効 であると考えられる。

そこで、実験に用いたすべてのシーンのデータを用い て、評価項目の影響力を求めることにした。まず、すべて のシーンの評価項目（評価の理由）1125項目を、実験者 2 名の合議制により、似通った意味のもの同士集めて『理由

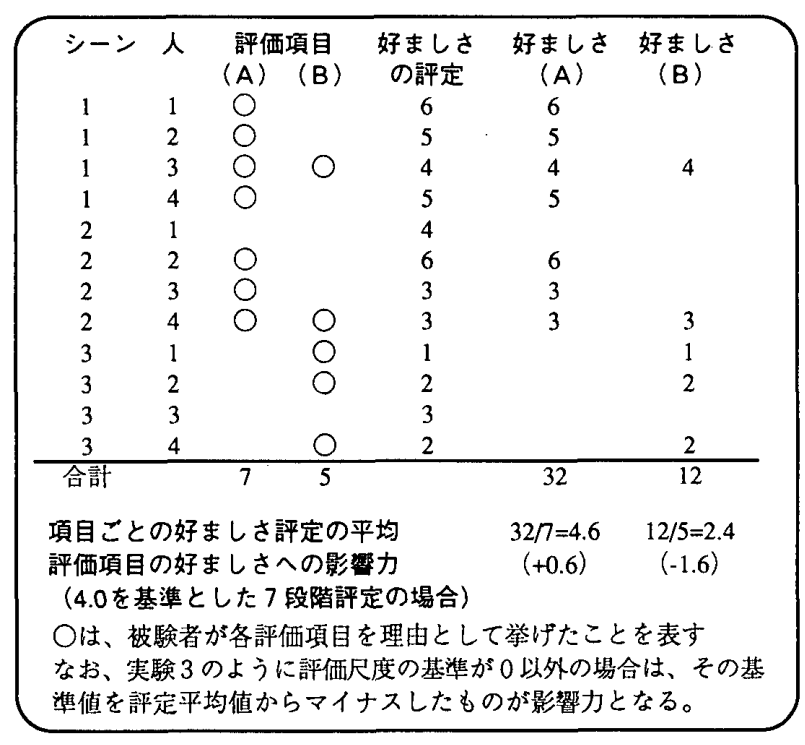

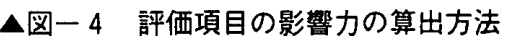

カテゴリー』を形成した。その結果、すべての詳価項目は 75の理由カテゴリーに分類された。次に、理由カテゴリー ごとに、そこに含まれる評価項目を理由として挙げたすべ てのシーンの「好ましさ」の評定平均値を算出し、これを 理由カテゴリーに含まれる評価項目が街路景観評価に及は す影響力とした [表一3］。注5

\section{4. 抽出された評価項目の影響力}

表一3には、評価への影響度を考慮する程度により、3 種類の影響力の值が示されている。被験者の記述した 5 段 階の影響度ごとに影響力を算出したのが $(-2 \sim+2) 、$ 評価へ の方向性ごとに影響度をまとめ、3 段階で影響力を算出し たのが $(-, 0,+) 、$ 全く影響度の違いを考慮していないallの 3 つである。検討すべき 2 つの可能性のうち、(1)「評価に 関連することが明らかなケースのみをデータとして影瑤力 を算出すること」だけを考虑したのがallであり、(2)「影響 力の方向性で分離して影笪力を算出すること」についても 考慮したのが $(-, 0,+)$ 、影響力の方向性だけでなく、その 度合についても考慮したのが(-2〜+2)ということになる。

ここでは、新たに求めた評価項目の影響力のデー夕を、 相関係数や偏回帰係数で表現された評価項目の影響力と比 較することにより、前述した $2 つ の$ 可能性を考慮すること の有效性を確認する。なお、相関係数や偏回帰係数は、実 験 2 ・ 3 と同じ街路景観スライドを用いた実験 1 の評定 データから求めた值（表一1の值）を用いている。

（1）評価の理由のみを影響力算出に用いることの有効性 図一ろからわかるように、評価の理由として挙げられる 項目はシーンによって異なっている。したがって、全ての シーンに共通な尺度を設定して求めた相関保数や偏回帰係 数で表現される影響力と、新しい手法による影響力では違 
いがあるはずである。しかし、表一 3 のallと実験 1 の偏回 帰係数や相関係数を比較してみると、算出された影鳌力に 違いがあるものは少なく、全般的には対応関係が見られ る。これは、強く感じられると評価の理由として挙げられ るという基本的な対応関係があるためだと考えられる。こ の対応関係は、後に示す図ー5において、理由カテゴリ一 ごとの因子得点の布置がドーナツ状をなしていることなど から確認できる（図ー 5 では、周辺部ほど強い印象を受け ていることを表している。）。归6

しかし、SD尺度の評定值としては極值をとりながら、 理由としては挙がってこない項目もある。これは、無意識 としては感じていながら、理由としては意識されない項目 であると考えられる。棓価項目のS D 尺度評定値と、それ が理由として挙げられるかどうかの対応を見ることで、3 つのパターンが見い出された。

(1) シーンの特徵を示すもので、そのシーンにおいては直 接評洒に影響を及ほさないもの

例えば、「広い」や「狭い」では、それが開放感や圧迫 感に結び付かないときには、評定では極值をとっても、理 由としては出てこないというような場合。

(2) 評洒に関連するシーンの特徽を表現したもの

(1)とは反对に、感じていることは親しみであるが、それ を感じせている主な特徴が生活景であるため、「生活感 のある」だけが理由として抽出されるというような場合。

(3) 同様の特徴や性格を表現するもの

親しみと温かみや、面白みと楽しそうのように、同じよ うな性格を持つ言葉は、シーンの特徽によって、どちらか 一方が偏って理由として抽出されるというような場合。

(2)、(3については、隠れていた評価項目も理由として挙 げられた項目と連動して変化しているため、SD法の評定 をもとにした解析でも、総合的な評価との関連を明らかに することができる。しかし、(1)に属する項目は、理由とし て用いられるときと、そうでないときを分離しないと影晦 力を抽出できない。

表一3でall と実験 1 の偏回帰係数に大きな違いがみられ た「活気がない」「狭い」「古い」「うるさい」「歴史を 感じる」「懐かしい」などは(1)に属する項目で、それぞれ

「寂しさ」「圧迫感」「污らしさ」「落ち着きのなさ」 「まとまり」「親しみやすさ」に結び付いたときだけ評価 に影響を及はしているのではないかと考えられる。注7

これとは反对に、「歩きやすい」は実験 1 の相関係数や 偏回帰係数が大きいにも関わらず、新しい手法では小さな 影響力しか抽出されていない。歩きやすいところはよく整 備された街路であるといったような、付随する条件が相関 係数や偏回帰係数を大きくしていたのたと考えられる。

このように、評価の理由となるケースだけを、評価項目 の影響力の算出に用いることは、理由が挙げられたときの 意味内容に対応する影響力を抽出することになり、より正
確な影響力の抽出に有効であることが確認された。

\section{（2）影粱力の方向性を考慮したことの有効性}

評価の理由だけを影響力の算出に用いることの有効性は 確認されたが、表ー3のallでは0.0付近のもの、つまり影 響力が抽出されたとは言えないものがある。例えば、「生 活感」は0.0を示しており、全く影響力が抽出されていな

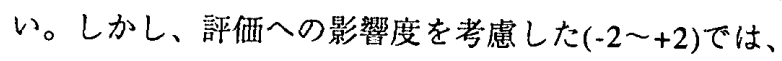
(+2)で+0.7、(-1)では-2.0の影響力が抽出されている。

表ー3には、「生活感」のように、ひとつの理由カテゴ リーの中でも、被験者が記述した評価への影龓度に違いが あり、方向性が異なるものが多数存在する。つまり、同じ 言葉で表現される評価項目であっても、影響力の方向性に 違いがあるケースが存在することが確認されたことにな る。それらの項目は、実際には影響力を持っていたのだ が、評価を上げる（十）ときと、評価を下げる（一）とき の方向性の違いを区別しなかったために、影響力が相殺さ れて小さく表現されていたのだと考えられる。

その方向性の違いが、何に起因するのかを明らかにする ために、評価項目の性格と名づけたデー夕を求めた。これ は、理由カテゴリーごとに、好ましさ以外のS D 法 9 尺度 についての評定平均値を求めたもので、各理由カテゴリー に属する評価項目が評価の理由として挙げられたシーンの 平均的な印象を示すものである。たたし、今回は影響度の 方向性の違いを見るために、理由カテゴリーをその方向性 で2つに分けてから解析した。そのデータ〔理由カテゴ リー（十，一）×S D法 9 尺度〕を因子分析したものを図 - 5 に示す。

評価項目の性格がどのようなものであるか知るために は、図の中心からのベクトルを読み取れば良い。例えば、 「統一感」が評価に十の影響を及はしてときはまとまりが 感じられているが、一の影響を及ほしている場合にはやや 親しみがないと感じられていることや、「生活感」が+の 影響を及ほしている場合には親しみや暖かみの成分が大き いのに対し、一の場合はまとまりがないことを意味してい る、といったことがこの図から読み取れる。

さて、影響度で表される方向性の違いが評価項目を感じ る度合の違いに起因しているなら、影栢度ごとに求めた評 価項目の性格は、中心からの方向性は同じで大きさの異な るベクトルとして因子得点布置図上に表現されるはずであ る。また、評価項目の重み付け（重視度）の違いが影響力 の違いの原因である場合も、ベクトルは近傍に集まり、そ の方向性は共通なはずである。しかし実験で得られた評価 項目の性格を表現するベクトルは、方向性が一定ではな い。つまり、評価への影壀力を変化させる主な要因は、こ の性格の違いによるものだと解釈される。

評価項目の性格の違いが評価への影響力を規定している ことを端的に示している例として、非常に強く生活が感じ 
表ー3 理由カテゴリーごとに求めた評価に及ぼす影響力

\begin{tabular}{|c|c|c|c|c|c|c|c|c|c|c|c|c|c|c|}
\hline \multirow{2}{*}{ 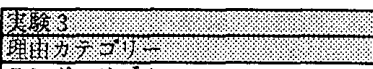 } & \multirow{2}{*}{\multicolumn{4}{|c|}{ (ail }} & \multirow{2}{*}{\multicolumn{2}{|c|}{ 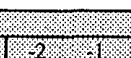 }} & \multicolumn{4}{|c|}{ 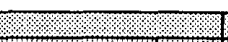 } & 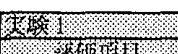 & $\sqrt{2}$ & 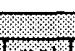 & (1) \\
\hline & & & & 1.7. & & & 0 & $\frac{1.1}{1.11}$ & $\frac{+2}{22}$ & $\frac{\mid}{3}$ & & & & \\
\hline बとり & 1.5 & 1.0 & & 1.5 & & 10 & & 0.9 & 1.7 & 4 & のったりとした & 0.81 & & 0.44 \\
\hline さわわか & 1.3 & & 0.0 & 1.3 & & & 10.0 & 0.8 & 1.6 & 4 & & & & \\
\hline 楽しい & 1.2 & & -1.0 & 1.2 & & & 8.0 & 0.8 & 1.4 & 15) & & & & \\
\hline 個性、变化のある & 1.1 & 0.0 & 0.1 & 1.3 & 0.5 .5 & 0.3 & 0.1[ & 1.0 & 1.5 & 15 & 㑬性のある & 0.63 & 0.56 & \\
\hline 扎杂加加， & 1.1 & -0.3 & 0.0 & 1.2 & 0.7. & 00. & 0.0 & 0.6 & 1.8 & 12 & 㧈しゃれ & 0.63 & & 0.47 \\
\hline 月6 & 1.0 & & -0.3 & 1.1 & & & 63. & 0.9 & 1.2 & 6 & 四るいい惩心゙ & 0.57 & 0.60 & \\
\hline 湓和、バランス & 0.9 & -0.2 & 0.0 & 1.0 & 03 & 01 & 0.0 & 0.8 & 1.3 & 21 & 闆和している & 0.55 & 0.79 & \\
\hline 安心、安金、安らき & 0.9 & & -0.5 & 0.9 & & & 0.5 & 0.6 & 1.2 & 13 & 交らぎ & 0.61 & & 0.66 \\
\hline 湆しげ & 0.8 & & -1.0 & 0.9 & & & (i) & 0.6 & 1.0 & 7 & & & & \\
\hline 磨史を感じる、重々しい & 0.8 & -0.8 & 0.3 & $\frac{1.1}{1.1}$ & 20 & 0.0 & 0.3 & 1.0 & 1.1 & 6 & 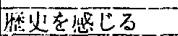 & 0.22 & & 0.26 \\
\hline 雩かしざ & 0.8 & 1.5 & 0.7 & 0.8 & & 15 & 0.7 & 0.5 & 1.1 & 1. & 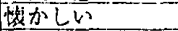 & 0.25 & & 0.23 \\
\hline 建物や色堁の繁四氛这い & 0.8 & 0.0 & & 0.8 & & $6 \%$ & & 0.3 & 1.2 & i1) & 建物 $I_{1}^{1} w^{2}$ & 0.72 & & \\
\hline きれい、美しい & 0.7 & -0.8 & 0.1 & 0.9 & $-0.7 \times$ & 1.5 & 0.1 & 0.5 & 1.2 & 38 & KLn & 0.82 & 0.66 & \\
\hline 极极 & 0.7 & 0.5 & -0.1 & 0.8 & & 0.5 & -0.1 & 0.6 & 1.2 & 10 & h & 0.48 & 0.53 & \\
\hline 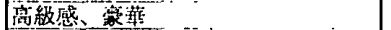 & 0.7 & -1.3 & 0.3 & 1.1. & 20.0 & 10 & 0.3 & 0.9 & 1.5 & 9 & 称級感のある & 0.53 & & 0.44 \\
\hline 落与尊当 & 0.7 & 0.3 & -0.2 & 0.7 & 0 s: & 00 & -0.2 & 0.5 & 1.1 & 22 & 济ち夜きのある & 0.71 & 0.59 & \\
\hline 直然発生的 & 0.7 & -1.0 & & 0.8 & 10. & & & 0.4 & & & & & & \\
\hline 温かみ、人情 & 0.6 & 0.3 & 0.0 & 0.7 & 0.5 . & 1.0 & 0.0 & 0.4 & 1.0 & 14 & 暖加感已 & 0.58 & 0.56 & \\
\hline 糫、自然がある & 0.6 & -0.6 & -0.7 & 0.7 & -0.3 & -0.8 & 0.7 & 0.4 & 1.1 & 26 & 線多い & 0.58 & 0.55 & \\
\hline 行動（生活、買い物など）しやすいい & 0.6 & & -2.0 & 0.7 & & & 2.06 & 0.4 & 0.9 & 7 & & & & \\
\hline 面白以 & 0.6 & -0.8 & -1.8 & 0.7 & -0.8 & & +8[ & 0.4 & 1.1 & 16 & 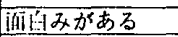 & 0.66 & 0.58 & \\
\hline 親しみ、身近か & 0.5 & -1.0 & 0.3 & 0.6 & & 100 & 03 & 0.4 & 0.8 & 15 & 牙近な & 0.43 & 0.44 & \\
\hline 整備されている、計画されている、 & 0.5 & -0.7 & -1.1 & 0.8 & -1.6 & 0.0 & $-1+1$ & 0.6 & 1.1 & 21 & 酔された & 0.27 & & 0.13 \\
\hline 新L6，近代的 & 0.4 & -1.0 & 0.0 & 0.7 & & .10 & 0.0 & 0.3 & 1.5 & 10 & 新しい & 0.17 & 0.11 & \\
\hline 酮 & 0.4 & -0.7 & -0.7 & 0.7 & $-1.3 \mid$ & -0.3 & 9.7 & 0.4 & 1.0 & 20 & まとまりがある & 0.05 & 0.42 & \\
\hline 期待感(二できうう) & 0.4 & -1.4 & -0.3 & 0.7 & $-1.5 \%$ & 10 & -0.3 & 0.3 & 1.2 & 14] & & & $\ldots$ & \\
\hline 弈道方いい & 0.4 & -0.5 & 0.7 & 0.4 & $0 \%$ & & 87. & 0.3 & 0.5 & & & & & \\
\hline 歩きやすい & 0.4 & 1.0 & -1.0 & 0.4 & 10 & & 10 & 0.3 & 0.6 & & 造きやすい & 0.53 & 0.79 & \\
\hline 庶民的、下町っはさ、コミュニティ & 0.3 & -1.0 & -0.3 & 0.5 & 1.15 & 0.5 & -0.3[ & 0.3 & 0.9 & 10 & 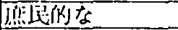 & -0.09 & & -0.38 \\
\hline 人闌味、ヒューマンスケール & 0.3 & -1.0 & -1.0 & 0.6 & $1,3.3$ & 0.5 & 1.0 & 0.5 & 0.6 & 8 & & & & \\
\hline 整然、守っきり、整っている & 0.3 & .1 .0 & -0.4 & 0.6 & -1.6 & -0.2 & -0.4 & 0.3 & 1.1 & 26 & 整然としている & 0.38 & 0.23 & \\
\hline 外国㾍 & 0.3 & -1.0 & -1.0 & 0.5 & & 100 & -1.0 & -0.1 & 1.1 & 5 & 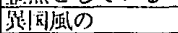 & 0.47 & & 0.41 \\
\hline 賑やか、活気 & 0.1 & -1.6 & -0.9 & 0.4 & 1.7. & 15 & -0.9 & 0.1 & 0.8 & 17 & 浙父がある & -0.08 & -0.06 & \\
\hline 開放感、㕕い、ゆったり & 0.1 & -1.2 & -1.1 & 0.3 & -1.2 & 13 & $-1+1$ & 0.11 & 0.6 & 42 & 苰W & 0.09 & 0.13 & \\
\hline 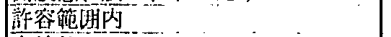 & 0.1 & & -0.4 & 0.5 & & & -0.4 & 0.6 & 000 & 3 & & & 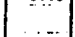 & \\
\hline 哑線似 & 0.1 & -0.1 . & & 0.7 & $0 \%$ & 0.0 . & & 0.0 & 10 & 3 & & & $\cdots$ & \\
\hline 生活感 & 0.0 & -2.3 & -0.5 & 0.3 & $2 \%$ & -2.0 & -0.5 & 0.0 & 0.7 & 12. & 雀活を兴じる & 0.09 & 0.08 & \\
\hline 楅画されていない、I夫を感じない & 0.0 & -0.3 & 0.0 & 1.7 & -1.1[ & 0.5 & 00.0. & 20. & 10 & 5 & 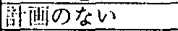 & -0.37 & & -0.27 \\
\hline 1 1メーシ $(\sim 5$ しさを感る & -0.1 & -1.2 & -0.5 & 0.4 & -2.0 & -0.9 & -0.5 & 0.1 & 0.8 & 12 & & & & \\
\hline 画舎 & -0.3 & -1.0 & -0.5 & 1.5 & 20. & 035 & -0.5 & 380 & 10 & 3 & & & & \\
\hline 一般的な街显み & -0.3 & -0.8 & -0.1 & 0.6 & -1.7 & -0.4[ & -0.1 & 0.4 & 20 & 10 & 灭な & -0.45 & & -0.43 \\
\hline 都会的 & -0.3 & -0.6 & -0.5 & 0.6 & -0.8 & -0.4 & -0.6 & 0.5 & 10 & 5 & & & & \\
\hline 理解不能、機能的でない & -0.4 & -0.4 & -1.0 & & -0.6 & -0.2 & 1.0. & & & 7 & & & & \\
\hline 人I的 & -0.6 & -0.7 & 0.7 & 1.3 & -1.3 & 0.0 & $.0 \%$ & 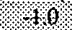 & 2.5 & & 人 [伿な & -0.32 & & -0.19 \\
\hline 算しい，活氛ない，闌敬 & -0.6 & -0.6 & -0.1 & 1.6 & -0.9 & -0.3 & -0.1 & 1.5. & 1.1 & 322 & 活父价ない & 0.08 & 0.06 & \\
\hline 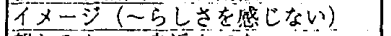 & -0.6 & -0.7 & 0.0 & 2.0 & -1.0 & -0.5. & .0 .0 & 20 & & 3. & & & & \\
\hline 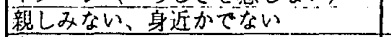 & -0.6 & -0.6 & -1.0 & & -0.7 & -0.5 & .10 & & & s. & & & & \\
\hline 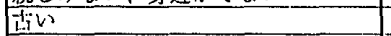 & -0.6 & -0.9 & -1.0 & 0.1 & -1.0 & -0.9 & +0 & 0.2 & 10 & 5 & $\sqrt{i=1}$ & -0.17 & -0.11 & \\
\hline プライバシーない & -0.7 & -0.8 & -2.0 & 1.0 & -1.1 & -0.5 & 20 & & & 2 & & & & \\
\hline 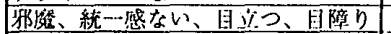 & -0.8 & -0.8 & -0.5 & 0.3 & -1.2 & -0.3 & -0.5 & 0.5 & $0 .+1$ & 60 & & & & \\
\hline$\partial ま ら な い$ & -0.8 & -0.8 & 0.0 & & -1.1 & -0.3 & 00 & & & 6 & & & & \\
\hline 不周和、ミスマッチ & -0.8 & -0.8 & -0.2 & 0.2 & -1.3 & -0.3 & -0.2 & -0.3 & 20 & 30 & 迵和していない & -0.55 & -0.79 & \\
\hline 歩きにくい & -0.8 & -0.8 & & & -1.1 & -0.5 & & & & 7 & 䨗さにくい & -0.53 & -0.79 & \\
\hline 㜓たい & -0.8 & -0.9 & -0.2 & 0.0 & -1.1 & -0.7 & -0.2 & 000 & & 14 & 甬たい感巨 & -0.58 & -0.56 & \\
\hline 女plew & -0.8 & -1.0 . & & 0.0 & -1.0 & -0.9 & & (int) & 10 & & 念っばい & -0.42 & & -0.35 \\
\hline 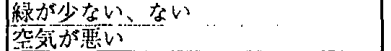 & $\begin{array}{l}-0.9 \\
-0.9\end{array}$ & $\begin{array}{l}-0.8 \\
-1.0\end{array}$ & -2.0 & 2.0 & $\begin{array}{r}-0.7 \\
-1.2\end{array}$ & $\begin{array}{l}-0.8 \\
-0.5\end{array}$ & 2,4 & 1. & & 5 & 秋少ない & -0.58 & -0.55 & \\
\hline 定安、危険 & -0.9 & -1.0 & 0.0 & 0.7 & $-1,2$ & -0.8 & 0.0 & 1.0 & 00 & 31 & & & & \\
\hline こちりこち & -0.9 & -1.0 & -0.8 & 0.9 & -1.4 & -0.6 & 0.8 & 0.8 & 1.1 & 38 & まとまりがない & -0.55 & -0.42 & \\
\hline 消潔感ない、污い & -0.9 & -0.9 & -1.0 & -0.7 & -1.3 & -0.6 & 10. & 0.3. & .20 & 27 & 新上Lい & -0.39 & -0.34 & \\
\hline I茺感、狭い & -1.0 & -1.1 & -0.5 & 0.9 & -1.5 & .0 .4 & -0.5 & 1.2 & $\theta .3$ & 61 & 炏 & -0.10 & -0.09 & \\
\hline 廒れ、悲しみ & -1.0 & -1.0. & & & -1.5 & -0.5 & & & & 9 & 遮れる & -0.77 & & \begin{tabular}{|l|}
-0.70 \\
\end{tabular} \\
\hline & -1.1 & -1.1 & -2.0 & & -1.2 & -0.8 & 20 & & & 4 & 榣い感E & -0.57 & -0.60 & \\
\hline 人阻害、䦎鎖的 & -1.1 & -1.1 & -1.0 & & -1.4 & -0.6 & $-1, \theta$. & & & 14 & & & & \\
\hline 权闽景 & -1.1 & -1.1 & -0.5 & 0.0 & -1.5 & -0.7 & -0.5 & 00 & & 15 & & -0.58 & & -0.38 \\
\hline 萳白くない & -1.1 & -1.2 & 0.0 & & -1.6 & .0 .6 & 0.0. & & & 17 & 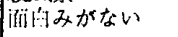 & -0.66 & -0.58 & \\
\hline 画一的、変化のない、個性無い & -1.2 & -1.2 & -1.3 & -0.4 & -1.6 & -0.6 & +3 & 0.3 & 3.6 & 22 & & & & \\
\hline 变通り風 & -1.2 & -1.6 & -0.8 & -0.3 & -1.6 & -1.6 & 0.8 & -0.3 & & 5 & & & & \\
\hline 行動（生活、買い物など）しにくい & -1.4 & -1.3 & & -2.0 & -2.0 & -0.5 & & & 2.8 & 3 & & & & \\
\hline & -1.5 & -1.5 & & & -1.9 & -0.8 & & & & 5 & 万るさい & -0.48 & -0.53 & \\
\hline 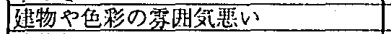 & -1.9 & -2.0 & -1.0 & $-1,0$ & -2.3 & & & & & 6 & & & & \\
\hline 機能的 & & & & & & & & & & 2 & & & & \\
\hline 何も感じない、恶通 & -0.2 & & .0 .2 & & & & -0.2 & & & 68 & & & & \\
\hline & & -0.5 & & & & & & & & & & & & \\
\hline
\end{tabular}

すべての值は、7段階尺度評定値をもとに算出

兆は、反応した人数が 3 人以下のカテゴリー

は、諭理的に不適当だと考えられるもの（注 4 参照）

allは、理由カテゴリーに属する評価項目を評価の理由とした全

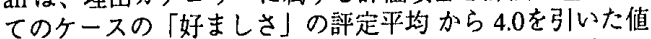

$(-, 0,+)(-2,-1,0,+1,+2)$ は、被験者が記述した影郘度で、各理

由カテゴリーを3段階、および5段階に分けて「好ましさ」の

評定平均をとったものから 4.0 をいた値
シー擞は、理由カテゴリーに屈する評亚項目を含むシーンの総計 corr、「好ましさ」と各項目の相関係数 (表-1参照) reglは、「好ましさ」と各項目の偏回帰係数で、表-1（C) のデータである。

reg2は、「好ましさ」と各項目を感じた人数との偏回栕係数 で、表ー1（B）のデータである。 
られている図ー6のシーンが挙げられる。このシーンで は、「生活感」の評定は被験者によらずほほ一定である が、「親しみ」は好ましいと感じた人ほど強く感じられて いる。つまり、生活を感じる量ではなく、生活のイメージ に対する親しみの度合によって評価が異なるのだと考えら れる。

このように、評価項目の影響力は、必ずしもその評洒項 目を感じる度合に対応して変化しているのではない。この ことは、評価項目が理由として挙げられたときに、評佃項 目と同じ言葉で表現されるSD尺度の評定值がどのような 值をとるかを、評価への影響度の区分ごとに示した表一 4 でも確認できる。整然や生活感のように、+一両方向に働 く項目であっても、各評価項目を感じる度合はそれほど変 化していない。

以上、評価項目の影響力の方向性が異なるケースが存在 することが確認され、方向性が変化するのは、評洒項目の 性格（情緒的な意味内容）が变化することが原因であるこ とがわかった。そして、方向性の違いを考慮することによ り、これまで抽出されなかった影響力を抽出することがで きた。このことから、影響力の方向性で評価項目を分けて から、垀価項目の影響力を抽出することの必要性が確認さ れたと言えよう。

\section{（3）街路詈観評価の予測}

最後に、ここで算出された各評価項目の影響力を用い て、各街路景観シーンの「好ましさ」がどの程度の精度で 予測可能かを検討した。

ただし、このとき用いた各評価項目の影響力を統合する 方法は、多属性効用理論の一般的な方法と異なるものなの で、説明を加えておく。多属性効用理論では、対象の評価 の予測を行う場合、各属性の効用の統合方法として効用加 算ルールを用いることが一般的である。これは、各属性の 効用（各評価項目の影響力）の合計に定数を加えれば、予 測評価值が得られるというものである。しかし、今回「好 ましさ」の予測に用いるデータは、理由となる評価項目の 数がシーンにより異なるので、各評価項目の影響力の合計 をとると、シーンによっては評価を実際より良く(悪く) 表現してしまい、予測精度は悪くなると考元られる。実 際、各評価項目の影響力の合計によるシーンの「好まし さ」の予測值と実際の評定の相関をとってみると、0.421 という低い值に留まった。この評価項目の数の問題を解消 するために、各シーンで評価の理由とされた評価項目の影 響力の平均（合計＼cjkstart個数）をとり、それを説明変数とした 単回帰分析を行うことにより、評価を予測した。

この方法で表ー3のallのデータから各街路景観シーンの 「好ましさ」を予測すると、実際の「好ましさ」の評定と の間に0.915という高い相関が得られた。実験でたずねた 評価への影響度を加味すると、3 段階のデー夕 $(-, 0,+)$ で

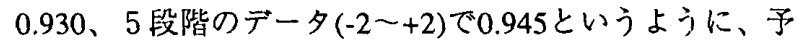
測精度はさらに向上した。このように高い相関をもって 街路景観の評価を予測できるということは、抽出された 評価項目の影響力の妥当性を示すと共に、評做項目がど の程度感じられるかを考慮しなくとも、どの評侀項目が 理由として挙げられるのかわかれば、十分に評偳を説明 できることを表していると考える。壮 8

\section{5. おわりに}

\section{（1）評価項目の影響力の抽出手法について}

評硕項目の影響力（評洒項目が街路景観評価に及浔す 影響）を正確に抽出するにはどうすればよいかを検討 し、新たな影響力抽出手法を提案した。今回提案した影 響力の抽出手法は、評価項目を街路景観評価の理由とし て挙げた全てのケースについて、総合的な評価一好まし さ」の評定平均をとるというもので、以下の点で S D尺 度の評定値をもとに相関保数や偏回帰俰数を計算すると いう手法より有効であると考える。

1）評価項目を理由として挙げるときの意味に対応した影 響力を抽出できる。

2）類似した意味をもつ項目が複数あっても、その影響力 を安定して抽出できる。

3）S D 尺度にすると極值を取るが、評洒に関連しないこ とがある評価項目についても、影響力を抽出できる。

この手法により抽出された影響力は、従来の相関係数 や偏回帰係数と異なる值を導き出す場合があり、理由と して述べられるケースのみを影響力の抽出に用いる必要 性が確認された。

さらに、被験者が記述した評価への影響度ごとに、評 価項目の影響力を算出することにより、同じ言葉で表現 されながら、影響力に違いのある評価項目が存在するこ とがわかった。特に、評価を上げるか下げるかという方 向性の違いは、評価項目の性格と名付けた情緒的意味内 容の違いに対応することが明らかになった。したがっ て、評価項目の影響力は、同じ言葉で表現される評価項 目であっても、その意味内容により分類してから抽出し なくては、正確な值を得られないことになる。その分類 の方法のひとつとして、被験者に記述させた影㗽度によ る方向性の分類が有効であると考える。

\section{（2）街路䀠観の評価研究についての展望}

これまで環境心理の分野では、物理的環境变数を変化 させた刺激を評定させる実験を行って、開放感や色彩調 和感といった感覚の強度を心理量として把握し、それを 物理的環境変数で表現するという陚みがなされできてい る。これは、開放感や調和感にはちょうど良いと感じら れる範囲があるので、その範囲に収まるよう物理的環境 


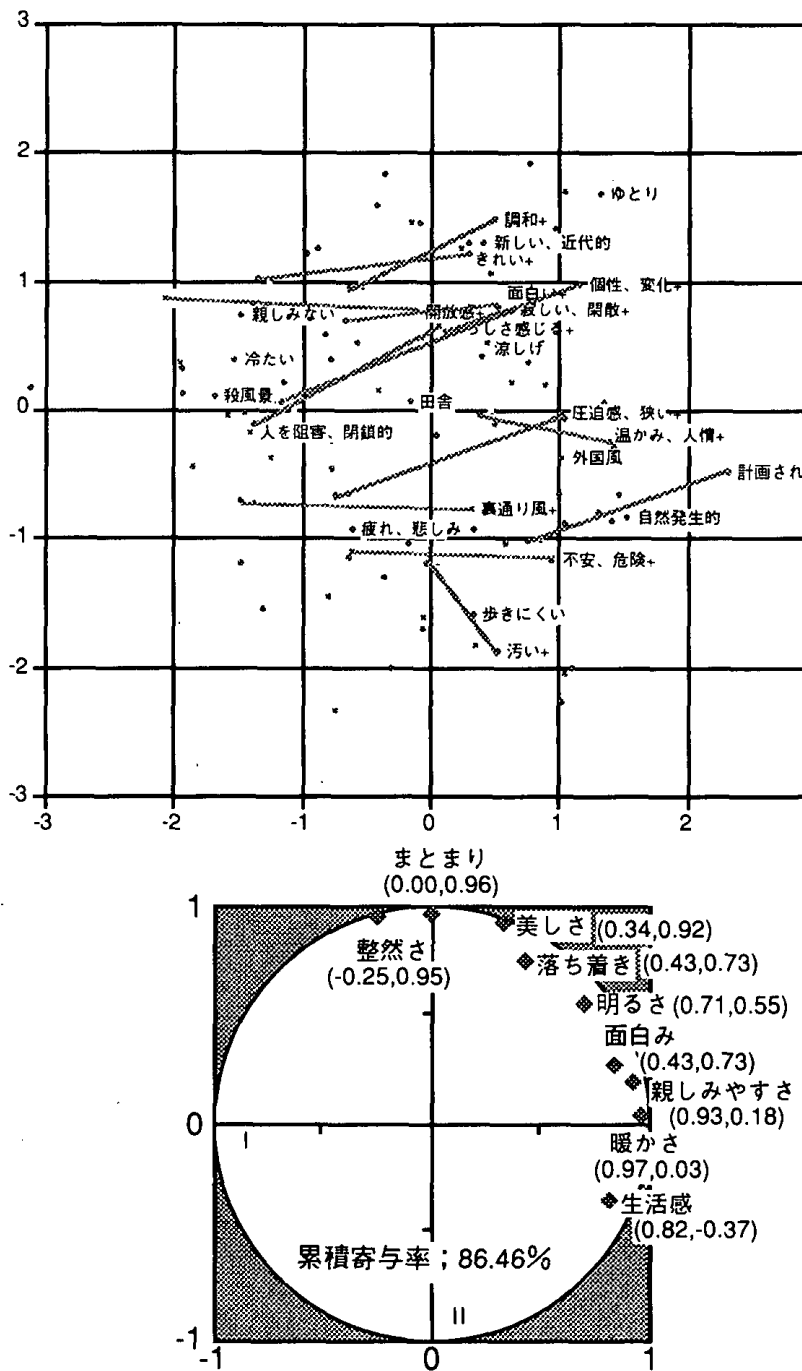

〈理由カテゴリーの性格の方向性を示す因子負荷図〉

因子得点布置図上で、線で結んであるのは、同じ理由カテゴリー で評価への影響の方向性が異なっているもの（+：評価を上げ る、一：評価を下げる)であり、+、一の記号が付いていないの は、方向性が一定しているものである

なお、因子得点布置図はもともとひとつであるが、見やすさを考

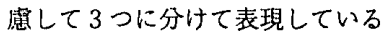

\begin{tabular}{|c|c|c|c|c|}
\hline 8 & (6) & (1) & 6) & 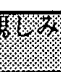 \\
\hline+5.2 & 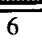 & F町の風情 & 今は尖われた風景、得の風棏....... 6.7 & 5.2 \\
\hline 4.6 & 5 & 金体の卯象 & 人䦌偠尙を感しる ……………………6.6 & 4.4 \\
\hline 4.5 & 4 & 路地 & 子佧が遊べる ........................................ 6.3 & 4.8 \\
\hline 4.5 & 11 & 生活 & 嗳かみ、人情味のある & 5.1 \\
\hline 4.0 & 16 & 植木など & 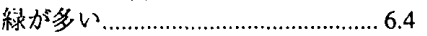 & 4.3 \\
\hline 4.0 & 8 & 全体の印缘 & 権多 & 4.5 \\
\hline 3.9 & 11 & 生活 & 生活感にあふれている、䒘心感..... 6.4 & 4.6 \\
\hline 3.1 & 16 & 路地 & 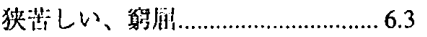 & 3.8 \\
\hline 3.0 & 12 & 植木など & 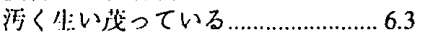 & 3.8 \\
\hline 2.9 & 11 & 生活 & ブライバシーのない & 3.2 \\
\hline 2.8 & 5 & 建物など & 洗練されていない................................ 6.8 & 3.8 \\
\hline 2.5 & 6 & 全体の印象 & 污らしい、浯潔感がない.................. 6.3 & 3.5 \\
\hline 2.4 & 9 & 家 & 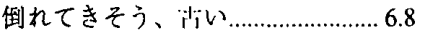 & 3.1 \\
\hline 2.0 & 5 & 仿人 & 難已などが伐んでいそう ................... 6.8 & 2.6 \\
\hline
\end{tabular}

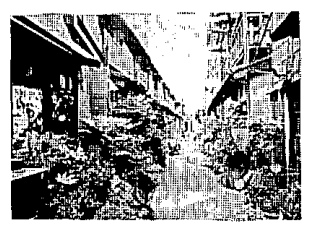

「好ましさ」「生活感」「親しみ」 は、そ机ぞれ4.0を中心とした7段階 S D 尺度評定值
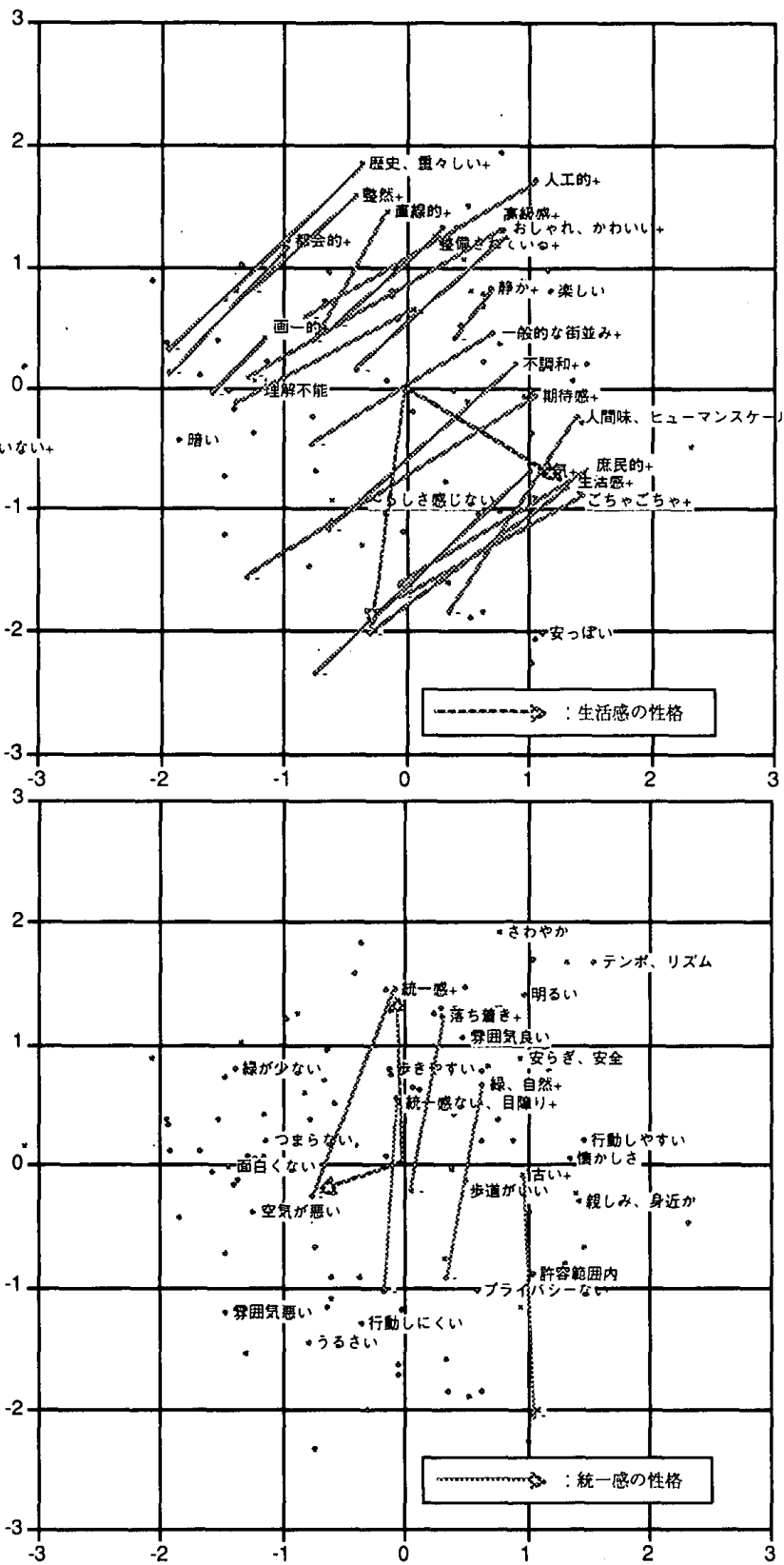

〈理由カテゴリーの性格を示す因子得点布置図〉

$\Delta$ 、図一 5 理由カテゴリーの性格の因子分析

、表一 4 評価への影響度ごとのS D 尺度の評定值

\begin{tabular}{|c|c|c|c|c|c|}
\hline 靕的 & 2 & 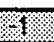 & 0 & W & 22 \\
\hline 美しい & 4.8 & 25 & 4.8 & 4.9 & 5.4 \\
\hline 整然 & 5.7 & 4.7 & 5.4 & 5.4 & 5.9 \\
\hline 落ち着き & 40 & 460 & 5.0 & 5.1 & 5.3 \\
\hline 明るい & & & 4.3 & 5.5 & 5.7 \\
\hline 暗い & 2.5 & 3.4 & 40 & & \\
\hline 面白い & 3.5 & & 4.0 & 4.6 & 5.5 \\
\hline 面白くない & 2.1 & 3.1 & 5.0 & & \\
\hline 生活感のある & 6.7 & 6.5 & 6.3 & 5.9 & 6.5 \\
\hline 親しみのある & & 5.0 & 4.3 & 500 & 5.2 \\
\hline 親しみのない & 2.9 & 3.3 & 20 & & \\
\hline 暖かい & 180 & 45 & 4.2 & 4.8 & 5.6 \\
\hline 冷たい & 2.4 & 3.0 & 3.6 & 3.0 & \\
\hline
\end{tabular}

評佂項目が理由として举げられたときの、その評価項目と同じ言葉 で表現される S D 尺度の評定值を4.0を中心とした 7 段階尺度で表 現したもの

は、理由として挙げた人数が 2 人以下の項目 
変数を制御することが、環境を向上させるのに役立つと考 えられていたためではないだろうか。

しかし今回、感覚量とそれが評洒に及はす影幚の度合 が、必ずしも相関しない場合があることがわかった。

ひとつには、その感覚（評価項目）が語価に関連しない ケースがあるためである。このようなケースでは、SD法 のような感覚量の評定はやれば〈できる〉ことではある が、普段評価をするときには〈やっていない〉ことなので

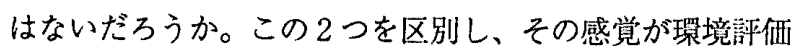
に関係するのはどのようなときなのかを明らかにする手段 として、S D尺度の評定と理由として感じられることの対 㐫を見ることが有効だと考える。

ふたつめに、同じ言葉で表現される感覚（評価項目）で あっても、その情緒的意味内容が異なる場合があり、意味 内容が翼なれば評価に及ほす影響の方向性が異なるという ことがある。このことから、評価との対応をとるのであれ ば、感覚量の表現以外に、評洒項目の意味という質的な違 いも、環境変数により表現していく必要があると考える。

このように、評価項目が理由として挙げられるのは街路 景観がどのような特徵を持つときなのか、影響力の方向性 の違いが街路景観のどんな特徴と関連しているのかを明ら かにしなくては、これまで行われてきた研究の成果を評価 構造の中に取り込んで表現することができない。今後、こ のような観点を備えた研究が增えることを希望する。

\section{謝 辞}

本研究の実験と解析の一部は、大学院生の山本早里氏と共同 で行った。ここに記して感謝の意を表します。

\section{注 袂}

注 1 個々の対象についての効用は、属性の評定値にある定数 を掛けたものとして表現される。しかし、評価構造としての 効用は、属性が評価に及はす影響の大きさに対応する定数自 体の大きさで表現してよいと考える。

(重回州式 $Y=\Sigma a x+b$ において、 $a x$ を効用と考えるの ではなく、 $\mathrm{a}$ を変数 $\mathrm{x}$ の効用として扱う)

注 2 本報で実験 1 と呼んでいるのは、既報》で報告した告験 3である。また、実験1に先だって、レパートリーグリッド 発展手法を用いて街路景観撞価の理由を把握したのは、既報1) の実験 2 に対応する。

注 3 相関保数は、変数間の関連の度合を表すことはできる が、一方の変数の変化が他方の変数を絶対値としてどれだけ 変化させるかを表現することはできない。したがって、評価 項目の影響力を表現する指標としては適当ではない。しか し、表一1 加わかるように、偏回帰係数との関連性も大き く、参考指標としての有効性はあると考える。

注 4 街路景観の評価は、多くの評価項目の影響力を統合した ものであろう。したがって、街路景観の評価から各評価項目 の影響力を抽出するには、各評価項目の影㗽力を区別するこ とが必要である。しかし、多くの評価項目が用いられ、それ らが複雑に変化する街路景観において、その区別をひとつひ とつ行うことは事実上不可能である。そこで、对象となって いる評価項目以外の評価項目の影響力については、なんらか の仮定を設けて、影響力を求めることになる。そのとき、あ る程度の数の評定サンブルがあるならば、対象となっている
評健項目以外の評価項目の影響力はランダムに分布すると考 え、それらの総和が 0 になると仮定することはそれ忹ど的外 れではないと考えたのである。

注 5 図一2の「着目した部分」の欄に示されている、特改的 な部分の違いが影響力を変化させる可能性もあるが、これを 考慮すると影響力を算出する際のケース数が非常に少なくな るため、今回の解析では考䡙していない。

さて、ここで抽出された影響力についても、いくつかの方 法で妥当性を確かめている。表一 3 に示された評怵項目の影

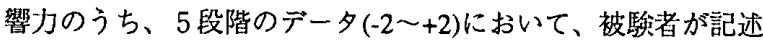
した評価への影帮度の順番と、その区分ごとに求めた評価へ の影㗽力の值の順番がうまく対応していれば、算出された影 響力の值はある程度妥当であると言ってよいだろう。表一 3 では、いくつか不整合のある部分が存在するものの、その多 くは1〜3人のごく少人数の評定から影響力を算出した場合 に起きている。したがって、ある程度の反応人数をもとに算 出された影響力の值隹、抒抒むね妥当性があると考元る。た だし、影響度 0 であるのに、影響力の值がその近傍にないも の(表ー3では、 \pm 0.5 以内にないものを目安に取消線を引い ている）、影響度と影響力の符号が異なるものも若干見られ る。これらの值の妥当性については今後別の実験データと比 較するなどの検討を行っていきたい。

注 6 表ー4 は、各評価項目と同じ言葉で表現される S D尺度 の評定值を、理由として挙げられたすべてのケースについ て、影響度ごとに平均したものである。それらは、影䪭度 0 の場合を除くと、打抢むね 4.0 加ら士1.0程度は離れた值を示し ている。このことも、評価の理由として挙げられるのは、強 く感じられた評価項目であることを示している。

注 7 实験 3 では、S D 尺度の評定を10項目についてしか行っ ていないため、「活気がない」が「等しさ」に結び付いたと きだけ評価に影響を及はすというような対応関係を明解に示 すことはできない。確認の必要があると言える。

注 8 算出された影皘力が実験 3 で提示したもの以外の街路景 観サンプルについても説明可能かどうかについては、別に同 様の評定実験を行い、今回求めた評価への影䈟力とどの程度 符合するか碓認する必要がある。そのとき、半主観的であっ た理由カテゴリーの設定方法についても検討したい。

\section{参考文献}

1) 槙 究、中村芳樹、乾 正雄：街路景観の評価構造の安定 性、日本建筑学会計画系論文集、No458、1994.4

2）小橋康章：決定を支援する（認知科学選㫮18）、東京大学 出版会、 1987

3）譛井純一郎、乾 正雄：レパートリー・グリット発展手法 に上る住環境語価粠造の抽出一諗知心理学に基づく住環境評 価に関する研究（1）一、日本建築学会計画系論文報告集、 No367、1986.9

4）讃井純一郎、乾 正雄：個人差及び階層性を考虑した住環 境評佂構造のモデル化一認知心理学に基づく住環境評価に関 する研究（2）一、日本建築学会計面系論文報告集、No374、 1987.4

5) 佐伯 㭌：認知科学の方法 (認知科学選書10)、東京大学 出版会、 1986

6）槙 究、山本早里、中村芳樹、乾 正雄：街路景観の評価 構造（その 1 : 特徵依存型Card-Pickupモデルの提管）、日 本建筑学会大会学術等演梗概集 (D)、pp939 940、1993

7) 山本早里、槙 究、中村芳樹、乾 正雄：街路景観の評価 構造 （その $2:$ 特徽依存型Card-Pickupモデルに基づいた評 価の表現）、日本建築学会大会学術講演梗概集（D）、pp941 $\sim 942 、 1993$

（1994年 7 月 8 日原稿受理，1994年12月15日採用決定） 